\title{
Improvement of the External Quantum Efficiency of Lithium Europium Tungstate and its Application to White Light Emitting Diodes
}

\author{
Tsutomu Odaki $*$, Tsutomu TAKano *, Kazuaki Hashimoto ** and Yoshitomo Toda $* *$
}

(Received November 9, 2006 ; Accepted April 24, 2007)

\begin{abstract}
In order to improve the quantum efficiency of the red phosphor $\mathrm{LiEu}_{0.96} \mathrm{Sm}_{0.04} \mathrm{~W}_{2} \mathrm{O}_{8}$ under $395 \mathrm{~nm}$ excitation, we synthesized samples having various particle sizes. We investigated the emission properties of near UV-pumped white LEDs containing this red phosphor. At room temperature, the external quantum efficiency improved to $49.4 \%$ as the particle size increased, a value comparable to that of commercialized green and blue phosphors used in n-UV LEDs.

In a white LED fabricated by combining an n-UV LED with RGB phosphors, including our synthesized $\mathrm{LiEu}_{0.96} \mathrm{Sm}_{0.04} \mathrm{~W}_{2} \mathrm{O}_{8}$, the luminance of an LED with a red phosphor particle size of $183 \mu \mathrm{m}$ was 1.6 times higher than that with a particle size of $21.7 \mu \mathrm{m}$. The color rendering properties showed excellent uniformity : there was no observable correlation between color rendering properties and particle size. We consider that an emission peak at $614 \mathrm{~nm}$ had a beneficial effect on the luminance and color rendering properties of a white light LED.
\end{abstract}

Key-words : $n$-UV LED, Quantum efficiency, $\mathrm{LiEu}_{0.96} \mathrm{Sm}_{0.04} \mathrm{~W}_{2} \mathrm{O}_{8}$, Luminance, Color rendering properties

\section{Introduction}

Since the first reports of a blue light emitting diode (LED) in 1993') and a white LED developed using this blue LED in 19972), the properties of white LED have been substantially improved, and the white LED field is currently undergoing remarkable changes. White LEDs are expected to be used not only for displays but also for general lighting applications because of their extended lifetime, low energy consumption, and environment-friendly characteristics. In recent years, white LEDs fabricated by combining InGaN-based blue LEDs with phosphor materials, such as YAG : $\mathrm{Ce}^{3+}$, have achieved high efficiency and are now widely used

* Fine Rubber R\&D Co., Ltd., C/O Asahi Rubber Co., $L t d$.

181, Nakamachi, Yabuki-machi, Nishi-Shirakawa-gun, Fukushima 969-0221, Japan

** Department of Life and Environmental Sciences, Faculty of Engineering, Chiba Institute of Technology 2-17-1, Tsudanuma, Narashino, Chiba 275-0016, Japan as backlights in small liquid crystal displays and as replacements for incandescent lamps. This type of LED, however, has a number of problems : the color of the white emission changes with input power; the color rendering index is low due to the mixing of the colors from the LED and the phosphor ; and the reproducibility is low due to the strong dependence of the white color quality on the amount of phosphor.

On the other hand, a white LED obtained by combining an InGaN-based near-UV emitting diode (n-UV LED) with three primary-color phosphors, that is, red, green, and blue phosphors, has a good rendering index. Presently, there is more interest on n-UV LEDs around $400 \mathrm{~nm}$, because they are promising candidates in higher efficiency solid-state lighting applications ${ }^{3)}$. However, the efficiency of white light obtained by combining n-UV LEDs with RGB phosphor materials is not necessarily high. One of the reasons is that there are only a few suitable phosphors for n-UV LEDs. In particular, there are demands for red phosphor with improved efficiency, because the efficiency is generally substantially lower than those of green and blue 
phosphors under n-UV excitation.

Recently, red phosphors with a scheelite structure have been investigated extensively ; for example, there have been reports of $\mathrm{NaEu}_{0.92} \mathrm{Sm}_{0.08}\left(\mathrm{MoO}_{4}\right)_{2}{ }^{4)}$, $\left.\mathrm{Ca}_{0.5} \mathrm{Li}_{0.25} \mathrm{Eu}_{0.25} \mathrm{MoO}_{4}{ }^{5}\right),\left(\mathrm{Li}_{0.333} \mathrm{Na}_{0.334} \mathrm{~K}_{0.333}\right) \mathrm{Eu}\left(\mathrm{MoO}_{4}\right)_{2}{ }^{6}$, and $\mathrm{AgGd}_{0.95} \mathrm{Eu}_{0.05}(\mathrm{~W}, \mathrm{Mo})_{2} \mathrm{O}_{8}{ }^{7}$. Our group synthesized $\mathrm{LiEuW}_{2} \mathrm{O}_{8}$ as a red phosphor with a scheelite structure for LEDs and reported its luminescence properties ${ }^{8)}$. $\mathrm{LiEuW}_{2} \mathrm{O}_{8}$ showed strong red emission intensity under 400 to $470 \mathrm{~nm}$ irradiation. We have also investigated the energy transport from $\mathrm{Sm}^{3+}$ ions to $\mathrm{Eu}^{3+}$ ions in $\mathrm{LiEu}_{0.96} \mathrm{Sm}_{0.04} \mathrm{~W}_{2} \mathrm{O}_{8}$ and showed that the excitation properties around $400 \mathrm{~nm}$ could be improved ${ }^{9)}$. So far, however, the efficiency of $\mathrm{LiEu}_{0.96} \mathrm{Sm}_{0.04} \mathrm{~W}_{2} \mathrm{O}_{8}$ has been lower than that of green or blue phosphor under n-UV excitation.

In the present study, we improved the efficiency of the red phosphor $\mathrm{LiEu}_{0.96} \mathrm{Sm}_{0.04} \mathrm{~W}_{2} \mathrm{O}_{8}$ by decreasing surface reflection. We also investigated the luminescence properties of white LEDs fabricated by combining n-UV LEDs with RGB phosphors.

\section{Experimental}

\subsection{Preparation of phosphors}

$\mathrm{LiEu}_{0.96} \mathrm{Sm}_{0.04} \mathrm{~W}_{2} \mathrm{O}_{8}$ was prepared from stoichiometric mixtures of $\mathrm{Li}_{2} \mathrm{CO}_{3}, \mathrm{Eu}_{2} \mathrm{O}_{3}, \mathrm{Sm}_{2} \mathrm{O}_{3}$, and $\mathrm{WO}_{3}$. The reactants were mixed with ethanol using a ball mill, placed in alumina crucibles, and heated at $900{ }^{\circ} \mathrm{C}$ for $6 \mathrm{~h}$. The samples were then cooled slowly to room temperature. The heated samples were pulverized with water in a ball mill. After drying, 3 mass \% water was added to granulate the pulverized samples, and they were heated again at $900^{\circ} \mathrm{C}$ for $6 \mathrm{~h}$. The samples were then crushed in an alumina mortar and were classified to obtain a prescribed particle size $\left(D_{50}\right)$ using a sieve.

\subsection{Preparation of silicone sheets containing RGB phosphors}

To obtain white LEDs, we mixed red, green, and blue phosphors in silicone rubber and molded the mixture into circular sheets with a thickness of $0.23 \mathrm{~mm}$ and a diameter of $5 \mathrm{~mm}$. In this study, we used $\mathrm{LiEu}_{0.96} \mathrm{Sm}_{0.04} \mathrm{~W}_{2} \mathrm{O}_{8}$ prepared as described above, or the purchased commercial red phosphor $\mathrm{La}_{2} \mathrm{O}_{2} \mathrm{~S}: \mathrm{Eu}^{3+}$ for comparison, as the red phosphors ; $\mathrm{ZnS}: \mathrm{Cu}, \mathrm{Al}$ as the green phosphor ; and $\mathrm{BaMgAl}_{10} \mathrm{O}_{17}: \mathrm{Eu}^{2+}$ as the blue phosphor. These phosphors were mixed at suitable ratios to produce white light having equal chromaticity (color temperature : $6500 \mathrm{~K}$ ), because the color rendering index of white light is influenced by the chromaticity.

\subsection{Characterization}

We used a laser diffraction particle size analyzer (Shimadzu, SALD-2200) to measure the particle size of the synthesized $\mathrm{LiEu}_{0.96} \mathrm{Sm}_{0.04} \mathrm{~W}_{2} \mathrm{O}_{8}$. The particle shape was observed using a scanning electron microscope (Keyence, VE7800), after coating the samples with $\mathrm{Au}$ in order to avoid the charging effect. We measured the spectral reflectance with a spectrophotometer (Shimadzu, CLR-7100F), and we measured the excitation and emission spectra with a spectrofluorometer (JASCO, FP-750) . We used a high-sensitivity multichannel spectrophotometer (Otsuka Electronics, MCPD-700) to measure the quantum efficiency under $395 \mathrm{~nm}$ irradiation from a xenon lamp.

The external quantum efficiency $\left(\eta_{\text {ext }}\right)$ of a phosphor is the ratio of the number of photons in the luminescence to the number of photons in the excitation applied to the phosphor. The internal quantum efficiency $\left(\eta_{\text {int }}\right)$ is the ratio of the number of photons in the luminescence to the number of excitation photons absorbed by the phosphor. The external and internal quantum efficiencies of the phosphor are given by equations (1) and (2) below ${ }^{10}$, where $E(\lambda)$ is the excitation spectrum, $R(\lambda)$ is the reflectance spectrum, and $P(\lambda)$ is the luminescence spectrum from the phosphor. The absorption ratios, external quantum efficiencies, and internal quantum efficiencies shown in this paper are values calculated from the results of measurement at room temperature.

$$
\begin{aligned}
& \eta_{\text {ext }}=\int_{\lambda 2}^{\lambda 1} \lambda \cdot P(\lambda) \mathrm{d} \lambda / \int_{\lambda 2}^{\lambda 1} \lambda \cdot E(\lambda) \mathrm{d} \lambda \\
& \eta_{\text {int }}=\int_{\lambda 2}^{\lambda 1} \lambda \cdot P(\lambda) \mathrm{d} \lambda / \int_{\lambda 2}^{\lambda 1} \lambda \cdot\{E(\lambda)-R(\lambda)\} \mathrm{d} \lambda
\end{aligned}
$$

\section{Results and Discussion}

\subsection{Improved quantum efficiency}

The excitation and emission spectra of the prepared $\mathrm{LiEu}_{0.96} \mathrm{Sm}_{0.04} \mathrm{~W}_{2} \mathrm{O}_{8}$ are illustrated in Fig. 1. Red luminescence with a peak at $614 \mathrm{~nm}$, due to the ${ }^{5} \mathrm{D}_{0} \rightarrow$ ${ }^{7} \mathrm{~F}_{2}$ transition of the $\mathrm{Eu}^{3+}$ ions, was observed in the emission spectrum. On the other hand, the excitation spectrum showed sharp bands with peaks at 381, 395, 416,465 , and $536 \mathrm{~nm}$. We reported already that a change in the excitation spectrum of $\mathrm{LiEuW}_{2} \mathrm{O}_{8}$ was observed by substituting $\mathrm{Eu}^{3+}$ ion sites with $\mathrm{Sm}^{3+}$ ions, and new excitation bands appeared at $403 \mathrm{~nm}$ and 470 to $500 \mathrm{~nm}^{9)}$.

Fig. 2 shows the energy levels of $\mathrm{Eu}^{3+}$ and $\mathrm{Sm}^{3+}$ ions, and the luminescence process in $\mathrm{LiEu}_{0.96} \mathrm{Sm}_{0.04} \mathrm{~W}_{2} \mathrm{O}_{8}$. The excitation spectrum is shown at the corresponding position at the right. The energy transport process from $\mathrm{Sm}^{3+}$ ions to $\mathrm{Eu}^{3+}$ ions in $\mathrm{LiEu}_{0.96} \mathrm{Sm}_{0.04} \mathrm{~W}_{2} \mathrm{O}_{8}$ is 
described below. When $\mathrm{LiEu}_{0.96} \mathrm{Sm}_{0.04} \mathrm{~W}_{2} \mathrm{O}_{8}$ is irradiated with photons having energies corresponding to the energy levels, the rare earth ions $\left(\mathrm{Eu}^{3+}\right.$ and $\left.\mathrm{Sm}^{3+}\right)$ absorb the energy. A wavelength of $403 \mathrm{~nm}$ is absorbed in $\mathrm{Sm}^{3+}$ ions at around $24.8 \times 10^{3} \mathrm{~cm}^{-1}$, which has an energy corresponding to $403 \mathrm{~nm}$, and the absorbed

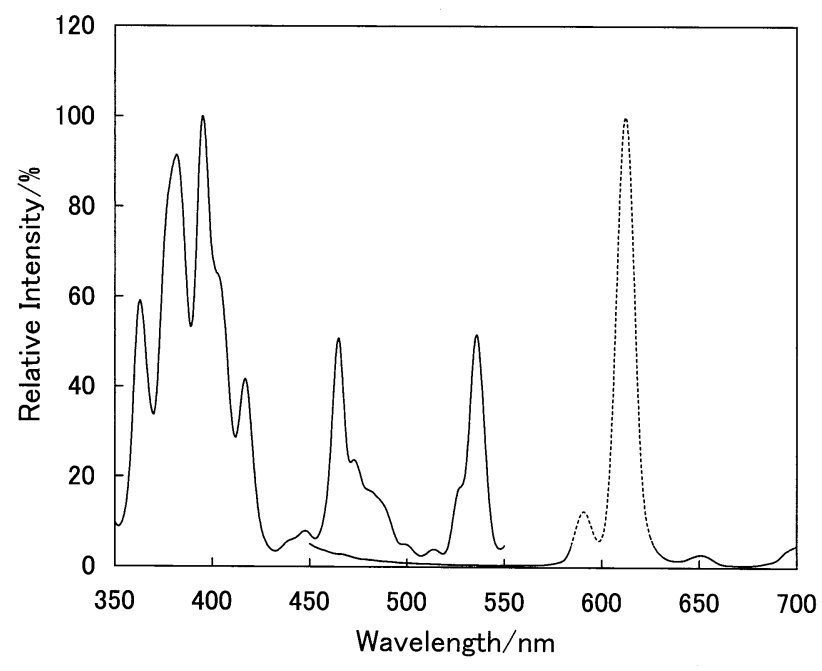

Fig. 1 Excitation (left) and emission (right) spectra of $\mathrm{LiEu}_{0.96} \mathrm{Sm}_{0.04} \mathrm{~W}_{2} \mathrm{O}_{8}$ at room temperature.

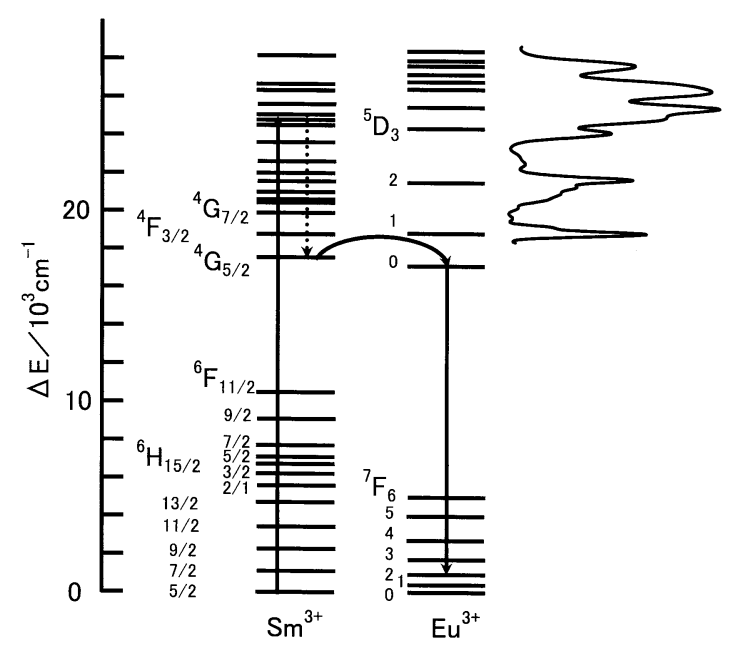

Fig. 2 Energy transfer and luminescence process in $\mathrm{LiEu}_{0.96} \mathrm{Sm}_{0.04} \mathrm{~W}_{2} \mathrm{O}_{8}$. energy relaxes to the ${ }^{4} \mathrm{G}_{5 / 2}$ level, which is a metastable level. Then, transportation of absorbed energy occurs from the ${ }^{4} \mathrm{G}_{5 / 2}$ level of the $\mathrm{Sm}^{3+}$ ions to the ${ }^{5} \mathrm{D}_{0}$ level of the $\mathrm{Eu}^{3+}$ ions. Finally, red luminescence with a peak at $614 \mathrm{~nm}$, due to the ${ }^{5} \mathrm{D}_{0} \rightarrow{ }^{7} \mathrm{~F}_{2}$ transition of the $\mathrm{Eu}^{3+}$ ions, is observed.

The agreement between the peaks in the excitation spectrum and the energy levels of the $4 \mathrm{f}$-electron in the $\mathrm{Eu}^{3+}$ and $\mathrm{Sm}^{3+}$ ions suggests that the 4 f-electrons in the $\mathrm{Eu}^{3+}$ and $\mathrm{Sm}^{3+}$ ions absorb the excitation energy directly. The sharp-band structure of the excitation spectrum, having several peaks at specific wavelengths, is due to the positions of the energy levels of the $4 \mathrm{f}$-electrons in the rare earth metal ions. However, the absorption ability of light by the rare earth metals ion is very low because the transition between $4 \mathrm{f}$ levels is forbidden. This causes the lower absorption ratio of the $\mathrm{LiEu}_{0.96} \mathrm{Sm}_{0.04} \mathrm{~W}_{2} \mathrm{O}_{8}$.

Table 1 shows the absorption ratio, internal quantum efficiency, and external quantum efficiency of phosphors used for n-UV LED. These quantum efficiencies were calculated from the results of measurement at room temperature under $395 \mathrm{~nm}$ excitation. The external quantum efficiency of the red phosphors was lower than that of the green and blue phosphors. Furthermore, the external quantum efficiency of $\mathrm{LiEu}_{0.96} \mathrm{Sm}_{0.04} \mathrm{~W}_{2} \mathrm{O}_{8}$ was lower than that of $\mathrm{La}_{2} \mathrm{O}_{2} \mathrm{~S}: \mathrm{Eu}^{3+}$. It is clear that the lower absorption ratio of $\mathrm{LiEu}_{0.96} \mathrm{Sm}_{0.04} \mathrm{~W}_{2} \mathrm{O}_{8}$ was due to the low external quantum efficiency.

Therefore, we prepared $\mathrm{LiEu}_{0.96} \mathrm{Sm}_{0.04} \mathrm{~W}_{2} \mathrm{O}_{8}$ with different particle sizes in an attempt to improve the absorption ratio. The particle size distributions (median size $: D_{50}$ ) of the synthesized samples are shown in Fig. 3. The particle sizes of the samples were 21.7, 49.1, $76.8,108,136$, and $183 \mu \mathrm{m}$ respectively. The color of the samples changed from very pale reddish white to pale reddish white as the particle size increased. Fig. 4 shows SEM photographs of samples with particle sizes of $21.7,76.8,108$, and $183 \mu \mathrm{m}$, respectively. From the results, it is clear that the synthesized samples were

Table 1 Quantum efficiency of RGB phosphors under 395nm excitation at room temperature.

\begin{tabular}{ccccc}
\hline Color & Phosphor & Absorption ratio/\% & $\begin{array}{c}\text { Internal quantum } \\
\text { efficiency }\left(\eta_{\text {int }}\right)\end{array}$ & $\begin{array}{c}\text { External quantum } \\
\text { efficiency }\left(\eta_{\text {ext }}\right)\end{array}$ \\
\hline \multirow{2}{*}{ Red } & $\mathrm{LiEu}_{0.96} \mathrm{Sm}_{0.04} \mathrm{~W}_{2} \mathrm{O}_{8}$ & 54.2 & 65.6 & 35.6 \\
& $\mathrm{La}_{2} \mathrm{O}_{2} \mathrm{~S}: \mathrm{Eu}^{3+}$ & 68.3 & 58.2 & 39.8 \\
& $\mathrm{Y}_{2} \mathrm{O}_{2} \mathrm{~S}: \mathrm{Eu}^{3+}$ & 37.7 & 34.4 & 13.0 \\
\hline \multirow{2}{*}{ Green } & $\mathrm{BaMgAl}_{10} \mathrm{O}_{17}: \mathrm{Eu}^{2+}, \mathrm{Mn}^{2+}$ & 55.2 & 75.9 & 41.9 \\
& $\mathrm{ZnS}: \mathrm{Cu}_{1} \mathrm{Al}$ & 70.7 & 69.1 & 48.8 \\
\hline \multirow{2}{*}{ Blue } & $(\mathrm{Sr}, \mathrm{Ca}, \mathrm{Ba})_{5}\left(\mathrm{PO}_{4}\right)_{3} \mathrm{Cl}: \mathrm{Eu}^{2+}$ & 66.2 & 78.4 & 51.9 \\
& $\mathrm{BaMgAl} \mathrm{O}_{10} \mathrm{O}_{17}: \mathrm{Eu}^{2+}$ & 62.8 & 78.9 & 49.6 \\
\hline
\end{tabular}




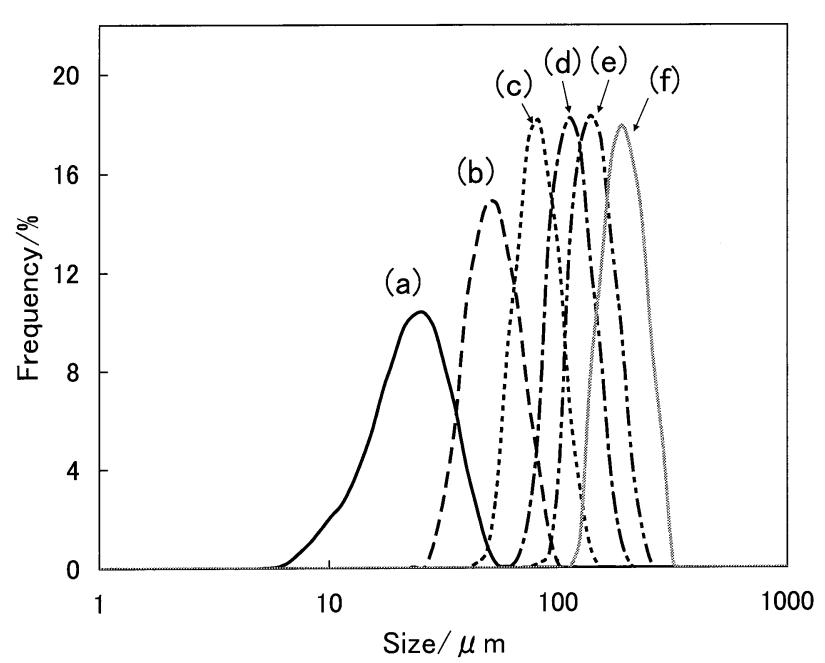

Fig. 3 Particle size distribution of synthesized samples. (a) $\mathrm{D}_{50}=21.7 \mu \mathrm{m}$, (b) $\mathrm{D}_{50}=49.1 \mu \mathrm{m}$, (c) $\mathrm{D}_{50}=$ $76.8 \mu \mathrm{m}$ ，(d) $\mathrm{D}_{50}=108 \mu \mathrm{m}$ ，(e) $\mathrm{D}_{50}=136 \mu \mathrm{m}$ ，(f) $\mathrm{D}_{50}=183 \mu \mathrm{m}$.
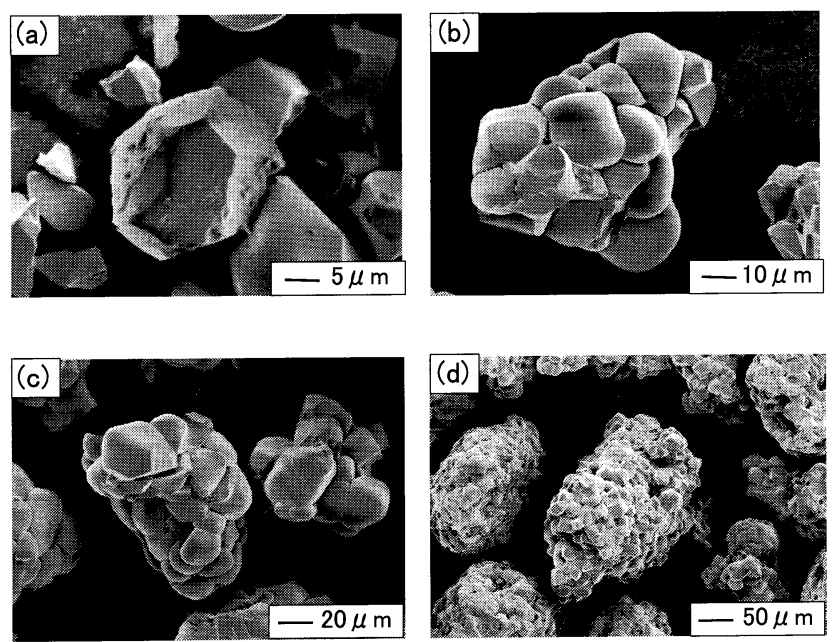

Fig. 4 Scanning electron microscope (SEM) photographs of synthesized samples. (a) $\mathrm{D}_{50}=21.7 \mu \mathrm{m}$, (b) $\mathrm{D}_{50}=76.8 \mu \mathrm{m}$ ，(c) $\mathrm{D}_{50}=108 \mu \mathrm{m}$ ，(e) $\mathrm{D}_{50}=183 \mu \mathrm{m}$.

aggregates of primary particles with sizes of 5 to $20 \mu \mathrm{m}$.

The effect of the particle size of $\mathrm{LiEu}_{0.96} \mathrm{Sm}_{0.04} \mathrm{~W}_{2} \mathrm{O}_{8}$ on the external quantum efficiency under $395 \mathrm{~nm}$ excitation is shown in Fig. 5. The external quantum efficiency improved from $35.6 \%$ to $49.4 \%$ as the particle size increased ; this value of $49.4 \%$ is as high as that of commercial green and blue emitting phosphors used in n-UV LEDs. The external quantum efficiency of the product seemed to saturate with a particle size of $136 \mu \mathrm{m}$ or more because no substantial change was observed.

Table 2 shows the relationship between the particle size of the samples and the absorption ratio, internal quantum efficiency, and external efficiency under $395 \mathrm{~nm}$ excitation. The internal quantum efficiency decreased

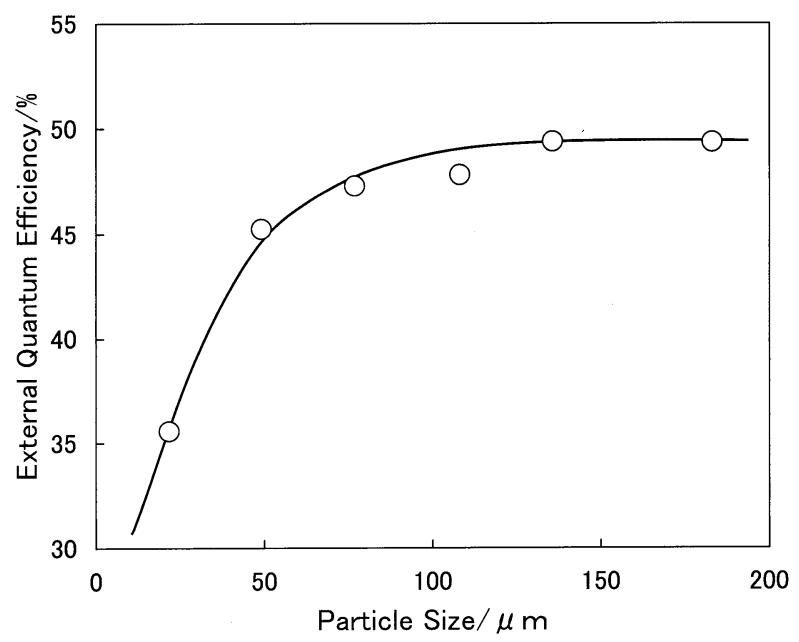

Fig. 5 Effect of the particle size of $\mathrm{LiEu}_{0.96} \mathrm{Sm}_{0.04} \mathrm{~W}_{2} \mathrm{O}_{8}$ on the external quantum efficiency under $395 \mathrm{~nm}$ excitation at room temperature.

Table 2 Relationship between particle size of $\mathrm{LiEu}_{0.96} \mathrm{Sm}_{0.04} \mathrm{~W}_{2} \mathrm{O}_{8}$ and quantum efficiency under $395 \mathrm{~nm}$ excitation at room temperature.

\begin{tabular}{cccc}
\hline Particle size/ $\mu \mathrm{m}$ & $\begin{array}{c}\text { Absorption } \\
\text { ratio/\% }\end{array}$ & $\begin{array}{c}\text { Internal quantum } \\
\text { efficiency }\left(\eta_{\text {int }}\right)\end{array}$ & $\begin{array}{c}\text { External quantum } \\
\text { efficiency }\left(\eta_{\text {ext }}\right)\end{array}$ \\
\hline 21.7 & 54.2 & 65.6 & 35.6 \\
49.1 & 67.1 & 67.4 & 45.2 \\
76.8 & 70.8 & 66.8 & 47.3 \\
108 & 73.3 & 65.2 & 47.8 \\
136 & 75.4 & 65.5 & 49.4 \\
183 & 76.9 & 64.2 & 49.3 \\
\hline
\end{tabular}

slightly as the particle size increased. On the other hand, the absorption ratio improved from $54.2 \%$ to $76.9 \%$ as the particle size increased. The improvement in external quantum efficiency of $\mathrm{LiEu}_{0.96} \mathrm{Sm}_{0.04} \mathrm{~W}_{2} \mathrm{O}_{8}$ is due to the improved absorption ratio because the product of absorption ratio and internal quantum efficiency is the external quantum efficiency.

We considered that this improvement in absorption ratio was probably attributable to the decrease of surface reflectance of the samples. Fig. 6 shows the spectral reflectance curves of the samples with particle sizes of $21.7,76.8,108$, and $183 \mu \mathrm{m}$ respectively. From these results, it is clear that the reflectance decreased at all wavelengths as the particle size increased, showing that the reflection at the phosphor surface did in fact decrease. This decrease in surface reflectance led to the improved absorption ratio.

One possible drawback, however, is that the decreased surface reflectance at all wavelengths causes the color of the phosphor to dull slightly. A clear host crystal for luminescence is one requirement of a good 


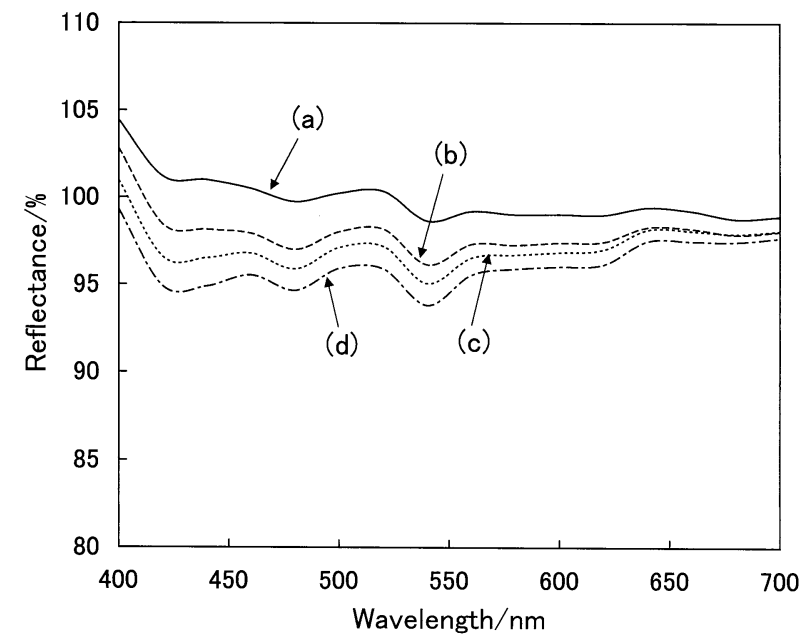

Fig. 6 Spectral reflectance curves of samples with difference particle sizes : (a) $\mathrm{D}_{50}=21.7 \mu \mathrm{m}$, (b) $\mathrm{D}_{50}=76.8 \mu \mathrm{m}$, (c) $\mathrm{D}_{50}=108 \mu \mathrm{m},(\mathrm{e}) \mathrm{D}_{50}=183 \mu \mathrm{m}$.

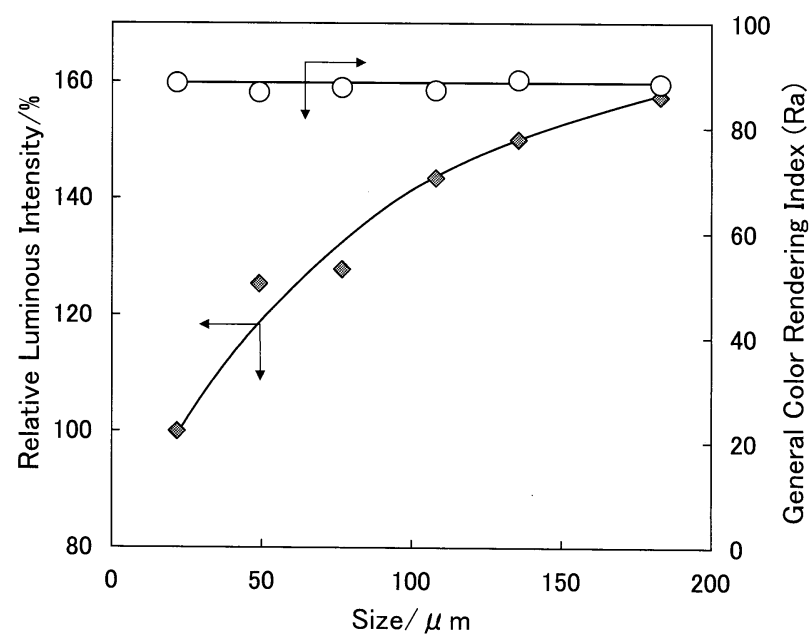

Fig. 7 Effect of the particle size of $\mathrm{LiEu}_{0.96} \mathrm{Sm}_{0.04} \mathrm{~W}_{2} \mathrm{O}_{8}$ on the emission properties of near UV-pumped white LED.

phosphor. In the case of an opaque host crystal, an efficient phosphor cannot be obtained due to absorption in the host crystal.

To summarize, we consider that the decreasing internal quantum efficiency of $\mathrm{LiEu}_{0.96} \mathrm{Sm}_{0.04} \mathrm{~W}_{2} \mathrm{O}_{8}$ as the particle size increased was caused by decreasing reflectance at around $600 \mathrm{~nm}$.

3.2 White light emitting properties

Fig. 7 shows the effect of the particle size of the samples on the emission properties of near UV-pumped white LEDs. In order to obtain white light, the phosphors we used were $\mathrm{LiEu}_{0.96} \mathrm{Sm}_{0.04} \mathrm{~W}_{2} \mathrm{O}_{8}$ for red, $\mathrm{ZnS}: \mathrm{Cu}, \mathrm{Al}$ for green, and $\mathrm{BaMgAl}_{10} \mathrm{O}_{17}: \mathrm{Eu}^{2+}$ for blue. The brightness of white light from the near UV-pumped LEDs increased as the particle size of the synthesized $\mathrm{LiEu}_{0.96} \mathrm{Sm}_{0.04} \mathrm{~W}_{2} \mathrm{O}_{8}$ increased. Moreover, the brightness of

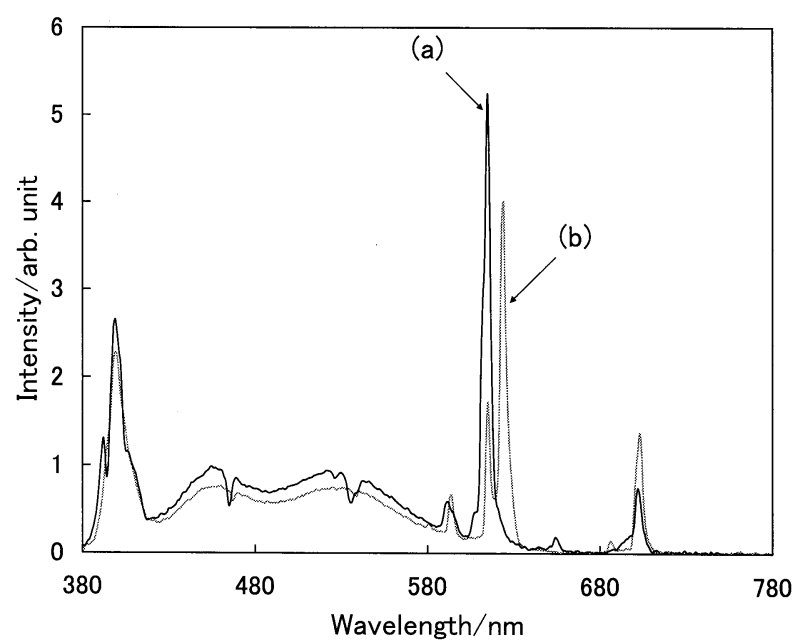

Fig. 8 Emission spectra of near UV-pumped white LEDs with RGB phosphors : (a) $\mathrm{R}=\mathrm{LiEu}_{0.96} \mathrm{Sm}_{0.04} \mathrm{~W}_{2} \mathrm{O}_{8}$, $\mathrm{G}=\mathrm{ZnS}: \mathrm{Cu}, \mathrm{Al}, \mathrm{B}=\mathrm{BaMgAl}_{10} \mathrm{O}_{17}: \mathrm{Eu}^{2+}$; (b) $\mathrm{R}=$ $\mathrm{La}_{2} \mathrm{O}_{2} \mathrm{~S}: \mathrm{Eu}^{3+}, \mathrm{G}=\mathrm{ZnS}: \mathrm{Cu}, \mathrm{Al}, \mathrm{B}=\mathrm{BaMgAl}_{10} \mathrm{O}_{17}$ : $\mathrm{Eu}^{2+}$.

the white light from an LED using phosphor with a particle size of $183 \mu \mathrm{m}$ was 1.6 times higher than that with a particle size of $21.7 \mu \mathrm{m}$. On the other hand, the general color rendering index $(\mathrm{Ra})$ was relatively constant and did not exhibit any substantial change with particle size.

Fig. 8 shows the emission spectra of two near UVpumped white LEDs with RGB phosphors, one using our synthesized $\mathrm{LiEu}_{0.96} \mathrm{Sm}_{0.04} \mathrm{~W}_{2} \mathrm{O}_{8}$ as the red phosphor and the other using commercial $\mathrm{La}_{2} \mathrm{O}_{2} \mathrm{~S}: \mathrm{Eu}^{3+}$ for comparison. In both LEDs, $\mathrm{ZnS}: \mathrm{Cu}, \mathrm{Al}$ and $\mathrm{BaMgAl}_{10} \mathrm{O}_{17}: \mathrm{Eu}^{2+}$ were used for the green and blue phosphors. From Fig. 8, it is clear that the emission peak of $\mathrm{La}_{2} \mathrm{O}_{2} \mathrm{~S}: \mathrm{Eu}^{3+}$ was located at a longer wavelength than that of $\mathrm{LiEu}_{0.96} \mathrm{Sm}_{0.04} \mathrm{~W}_{2} \mathrm{O}_{8}$. In each spectrum, the emission intensities around 465 and $535 \mathrm{~nm}$ were decreased due to absorption by the $\mathrm{Eu}^{3+}$ ions, as can be understood from the excitation spectrum shown in Fig. 1. In the spectrum of the $\mathrm{LiEu}_{0.96} \mathrm{Sm}_{0.04} \mathrm{~W}_{2} \mathrm{O}_{8}$-based LED, penetration light of the near UV-LED was observed in the range of 380 to $420 \mathrm{~nm}$, and its spectrum was divided into two regions. $\mathrm{LiEu}_{0.96} \mathrm{Sm}_{0.04} \mathrm{~W}_{2} \mathrm{O}_{8}$ selectively absorbed at $395 \mathrm{~nm}$.

The chromaticity, color temperature, relative luminance, and color rendering index were calculated from these spectra, and the results are shown in Table 3. These white LED using $\mathrm{LiEu}_{0.96} \mathrm{Sm}_{0.04} \mathrm{~W}_{2} \mathrm{O}_{8}$ (sample (a)) or $\mathrm{La}_{2} \mathrm{O}_{2} \mathrm{~S}: \mathrm{Eu}^{3+}$ (sample (b)) as the red phosphor had almost the same chromaticity and color temperature. The luminance values, however, were substantially different. The LED using $\mathrm{LiEu}_{0.96} \mathrm{Sm}_{0.04} \mathrm{~W}_{2} \mathrm{O}_{8}$ with a particle size of $183 \mu \mathrm{m}$ had a luminance 1.22 times higher than that using $\mathrm{La}_{2} \mathrm{O}_{2} \mathrm{~S}: \mathrm{Eu}^{3+}$. Moreover, the general 
Table 3 Emission properties of a near UV-pumped white LED with RGB phosphors.

\begin{tabular}{|c|c|c|c|}
\hline \multicolumn{2}{|l|}{ Sample } & (a) & \multirow{4}{*}{$\begin{array}{c}\text { (b) } \\
\mathrm{La}_{2} \mathrm{O}_{2} \mathrm{~S}: \mathrm{Eu}^{3+} \\
\mathrm{ZnS}: \mathrm{Cu}, \mathrm{Al} \\
\mathrm{BaMgAl}_{10} \mathrm{O}_{17}: \mathrm{Eu}^{2+}\end{array}$} \\
\hline \multirow{3}{*}{ Phosphor } & $\mathrm{R}$ & $\mathrm{LiEu}_{0.96} \mathrm{Sm}_{0.04} \mathrm{~W}_{2} \mathrm{O}_{8}$ & \\
\hline & $\mathrm{G}$ & $\mathrm{ZnS}: \mathrm{Cu}, \mathrm{Al}$ & \\
\hline & $\mathrm{B}$ & $\mathrm{BaMgAl}_{10} \mathrm{O}_{17}: \mathrm{Eu}^{2+}$ & \\
\hline \multirow{2}{*}{ Chromaticity } & $x$ & 0.3120 & 0.3104 \\
\hline & $y$ & 0.3265 & 0.3259 \\
\hline \multicolumn{2}{|c|}{ Color temperature / $\mathrm{K}$} & 6565 & 6659 \\
\hline \multicolumn{2}{|c|}{ Relative luminance / \% } & 122 & 100 \\
\hline $\begin{array}{l}\text { General color } \\
\text { rendering index }\end{array}$ & $\mathrm{Ra}$ & 88 & 81 \\
\hline \multirow{15}{*}{$\begin{array}{l}\text { Special color } \\
\text { rendering index }\end{array}$} & $\mathrm{R} 1$ & 79 & 75 \\
\hline & $\mathrm{R} 2$ & 91 & 92 \\
\hline & R3 & 96 & 88 \\
\hline & R4 & 82 & 75 \\
\hline & R5 & 85 & 81 \\
\hline & R6 & 84 & 87 \\
\hline & $\mathrm{R} 7$ & 95 & 87 \\
\hline & $\mathrm{R} 8$ & 94 & 67 \\
\hline & R9 & 85 & 18 \\
\hline & $\mathrm{R} 10$ & 84 & 87 \\
\hline & $\mathrm{R} 11$ & 78 & 73 \\
\hline & $\mathrm{R} 12$ & 90 & 91 \\
\hline & $\mathrm{R} 13$ & 83 & 80 \\
\hline & $\mathrm{R} 14$ & 95 & 90 \\
\hline & $\mathrm{R} 15$ & 82 & 70 \\
\hline
\end{tabular}

color rendering index $(\mathrm{Ra})$ of the $\mathrm{LiEu}_{0.96} \mathrm{Sm}_{0.04} \mathrm{~W}_{2} \mathrm{O}_{8-}$ based LED was 88, which is an excellent value. In terms of R9, which is a special color rendering index for red emission, the $\mathrm{LiEu}_{0.96} \mathrm{Sm}_{0.04} \mathrm{~W}_{2} \mathrm{O}_{8}$-based LED exhibited an excellent value compared with the $\mathrm{La}_{2} \mathrm{O}_{2} \mathrm{~S}: \mathrm{Eu}^{3+}{ }_{\text {-based LED. }}$

The reason for the difference between luminance and color rendering properties despite the materials showing almost the same chromaticity and color temperature is that the emission peak of $\mathrm{LiEu}_{0.96} \mathrm{Sm}_{0.04} \mathrm{~W}_{2} \mathrm{O}_{8}(614 \mathrm{~nm})$ was located at a shorter wavelength than that of $\mathrm{La}_{2} \mathrm{O}_{2} \mathrm{~S}: \mathrm{Eu}^{3+}(624 \mathrm{~nm})$. In the red region, the spectral luminance efficiency for the human eye drops rapidly toward longer wavelengths. In terms of luminance, therefore, a spectrum with a peak at a shorter wavelength is advantageous in the red region. Another reason is that we considered that the green and blue phosphors were able to emit light efficiently except at $395 \mathrm{~nm}$ because $\mathrm{LiEu}_{0.96} \mathrm{Sm}_{0.04} \mathrm{~W}_{2} \mathrm{O}_{8}$ absorbed selectively at $395 \mathrm{~nm}$.

Color rendering is the property of a light source that changes the color of the object illuminated by that light source. In the case of a light source with a broad continuous spectrum, high color rendering can be obtained because its spectrum is close to that of a reference light source, such as synthetic daylight and a full radiator (blackbody radiator). However, it is necessary that part of the emission energy of a broad continuous spectrum be distributed at both ends of the visible wavelength region, such as deep blue and red, resulting in a decrease in total luminous efficiency. Therefore, narrow emission bands have been used to realize high efficiency and high color rendering in fluorescent lamps. The reason is that the human eye has strong color visual responses in narrow wavelength bands around 450, 540 and $610 \mathrm{~nm}^{11}$. Most colors can be reproduced using a light source with an emission spectrum consisting of a combination of very narrow emission bands at these wavelengths. Based on this theory, high color rendering can be obtained without some wavelengths in the region of low luminous efficiency. The difference in emission peak positions between $\mathrm{LiEu}_{0.96} \mathrm{Sm}_{0.04} \mathrm{~W}_{2} \mathrm{O}_{8}$ and $\mathrm{La}_{2} \mathrm{O}_{2} \mathrm{~S}: \mathrm{Eu}^{3+}$ is only $10 \mathrm{~nm}$; however, the color rendering properties of white light LEDs using these red phosphors were different. We believe this was because the emission peak position of $\mathrm{LiEu}_{0.96} \mathrm{Sm}_{0.04} \mathrm{~W}_{2} \mathrm{O}_{8}$ is more suitable for the color visual response of the human eye than that of $\mathrm{La}_{2} \mathrm{O}_{2} \mathrm{~S}: \mathrm{Eu}^{3+}$.

\section{Conclusion}

We improved the efficiency of the red phosphor $\mathrm{LiEu}_{0.96} \mathrm{Sm}_{0.04} \mathrm{~W}_{2} \mathrm{O}_{8}$ by increasing the particle size, and we investigated the luminescence properties of white LEDs fabricated by combining n-UV LEDs with RGB phosphors, including $\mathrm{LiEu}_{0.96} \mathrm{Sm}_{0.04} \mathrm{~W}_{2} \mathrm{O}_{8}$. Despite the use of a red phosphor in which rare earth ions absorb the excitation wavelength directly by a forbidden transition, we improved external quantum efficiency to a level as good as that of commercial green and blue phosphors.

The synthesized samples were aggregates of primary particles with sizes of 5 to $20 \mu \mathrm{m}$. At room temperature, the external quantum efficiency was improved from $35.6 \%$ to $49.4 \%$ as the particle size increased. This improvement of the external quantum efficiency was attributable to the decrease of surface reflectance caused by the increasing particle size. The external quantum efficiency of $49.4 \%$ is as high as that of commercial green and blue phosphors used for n-UV LEDs.

As a result of investigation of the luminescence properties of white LEDs fabricated by combining n-UV LED with RGB phosphors, the luminance of a white light LED using our phosphor with a particle size of $183 \mu \mathrm{m}$ was 1.6 times higher than one with a particle size of $21.7 \mu \mathrm{m}$. The general color rendering index $(\mathrm{Ra})$ of the white LED was 88, a comparatively excellent value. In particular, the $\mathrm{R} 9$ value, which is a special color rendering index for red emission, was 85 . We consider that the emission peak at $614 \mathrm{~nm}$ had a beneficial 
effect on the luminescence and color rendering properties of the white light LED using our synthesized red phosphor.

\section{References}

1) S. Nakamura, M. Senoh, and T. Mukai : Appl. Phys. Lett., 62, 2390 (1993).

2) S. Nakamura and G. Fasol : The Blue Laser Diode, p.216, Springer, Berlin (1997).

3) D. A. Steigerwald, J. C. Bhat, D. Collins, R. M. Fletcher, M. O. Holcomb, M. J. Ludowise, P. S. Martin, and S. L. Rudaz : IEEE J. Sel. Top. Quantum Electron., 8, 310 (2002).

4) Z. Wang, H. Liang, M. Gong, and Q. Su :
Electrochem. Solid-State Lett., 8, H33 (2005).

5) J. Mang, X. Jing, C. Yan, and J. Lin : J. Electrochem. Soc., 152, G186 (2005).

6) Z. Wang, H. Liang, L. Zhou, H. Wu, M. Goug, and Q. Su : Chem. Phys. Lett., 412, 313 (2005).

7) V. Sivakumar and U. V. Varadaraju : J. Electrochem. Soc., 152, H168 (2005).

8) T. Odaki, K. Takagi, K. Hashimoto, and Y. Toda : J. Jpn. Soc. Colour Mater., 74, 495 (2001).

9) T. Odaki, K. Hashimoto, K. Yoshida, and Y.Toda : J. Jpn. Soc. Colour Mater., 77, 163 (2004).

10) K. Ohkubo and T. Shigeta : J. Illum. Engng. Inst. Jpn., 83, 87 (1999).

11) W.A. Thornton: J.Opt. Soc. Am., 62-2, 191 (1972).

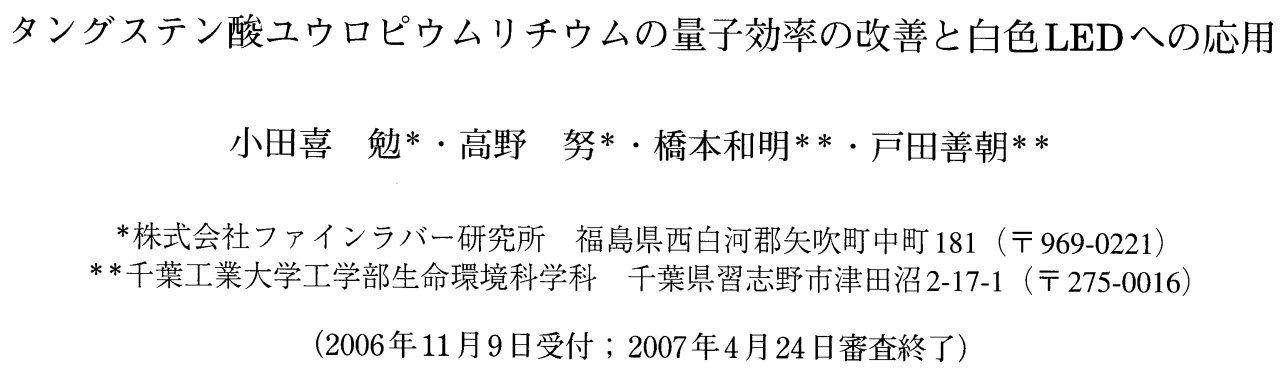

$395 \mathrm{~nm}$ 励起に扔ける $\mathrm{LiEu}_{0.96} \mathrm{Sm}_{0.04} \mathrm{~W}_{2} \mathrm{O}_{8}$ の量子効率を改善するため，異なる粒子径をもつ試料を調製した。また，調製した赤 色蛍光体が白色 LED の発光特性に与える影響を調查した。 $\mathrm{LiEu}_{0.96} \mathrm{Sm}_{0.04} \mathrm{~W}_{2} \mathrm{O}_{8}$ の粒子径を増大させることによって外部量子効率 は $49.4 \%$ \%で向上した。これは近紫外LED用の緑および青色蛍光体の外部量子効率に匹敵する值であった。

白色 $\mathrm{LED}$ ○応用を試みた結果, $\mathrm{LiEu}_{0.96} \mathrm{Sm}_{0.04} \mathrm{~W}_{2} \mathrm{O}_{8}$ の粒子径の増大にともない白色光の輝度は向上し，粒子径は $21.7 \mu \mathrm{m}$ の 赤色蛍光体を使用した白色光と比べると粒子径 $183 \mu \mathrm{m}$ の赤色蛍光体を使用した白色光は 1.6 倍の明るさが得られた。また，得 られる白色光の演色性は粒子径にかかわらず良好な值が得られた。 $\mathrm{LiEu}_{0.96} \mathrm{Sm}_{0.04} \mathrm{~W}_{2} \mathrm{O}_{8}$ の発光ピークが $614 \mathrm{~nm}$ に位置しているこ とが白色 LEDの輝度および演色性に影響を及ばしていると考えた。 